\title{
Identification and characterisation of an ostreid herpesvirus-1 microvariant (OsHV-1 $\mu$-var) in Crassostrea gigas (Pacific oysters) in Australia
}

\author{
Cheryl Jenkins ${ }^{1, *}$, Paul Hick ${ }^{1}$, Melinda Gabor ${ }^{1}$, Zoe Spiers ${ }^{1}$, Shayne A. Fell ${ }^{1}$, \\ Xingnian $\mathrm{Gu}^{1}$, Andrew Read ${ }^{1}$, Jeffrey Go ${ }^{1,2}$, Michael Dove ${ }^{3}$, Wayne O'Connor $^{3}$, \\ Peter D. Kirkland ${ }^{1}$, Jane Frances ${ }^{3}$
}

${ }^{1}$ NSW Department of Primary Industries, Elizabeth Macarthur Agricultural Institute, Menangle, New South Wales 2568, Australia

${ }^{2}$ Faculty of Veterinary Science, University of Sydney, New South Wales 2570, Australia

${ }^{3}$ NSW Department of Primary Industries, Port Stephens Fisheries Institute, Port Stephens, New South Wales 2316, Australia

\begin{abstract}
Between November 2010 and January 2011, triploid Crassostrea gigas (Pacific oysters) cultivated in the Georges River, New South Wales, experienced $>95 \%$ mortality. Mortalities also occurred in wild diploid C. gigas in the Georges River and shortly thereafter in the adjacent Parramatta River estuary upstream from Sydney Harbour. Neighbouring Saccostrea glomerata (Sydney rock oysters) did not experience mortalities in either estuary. Surviving oysters were collected to investigate the cause of mortalities. Histologically all oysters displayed significant pathology, and molecular testing revealed a high prevalence of ostreid herpesvirus-1 (OsHV-1). Quantitative PCR indicated that many C. gigas were carrying a high viral load at the time of sampling, while the load in $S$. glomerata was significantly lower $(\mathrm{p}<0.001)$. Subsequent in situ hybridisation experiments confirmed the presence of a herpesvirus in C. gigas but not S. glomerata tissues, suggesting that $S$. glomerata is not susceptible to infection with OsHV-1. Naïve sentinel triploid C. gigas placed in the Georges River estuary in January 2011 quickly became infected and experienced nearly $100 \%$ mortality within 2 wk of exposure, indicating the persistence of the virus in the environment. Phylogenetic analysis of sequences derived from the C2/C6 region of the virus revealed that the Australian strain of OsHV-1 belongs to the microvariant ( $\mu$ var) cluster, which has been associated with severe mortalities in C. gigas in other countries since 2008. Environmental data revealed that the Woolooware Bay outbreaks occurred during a time of considerable environmental disturbance, with increased water temperatures, heavy rainfall, a toxic phytoplankton bloom and the presence of a pathogenic Vibrio sp. all potentially contributing to oyster stress. This is the first confirmed report of OsHV-1 $\mu$-var related C. gigas mortalities in Australia.
\end{abstract}

KEY WORDS: Viral disease - Triploid - Bivalve · Aquaculture - Environmental stressor · Phytoplankton · Bloom · Biotoxin · Vibrio $\cdot$ New South Wales

\section{INTRODUCTION}

Herpesviruses that infect bivalve species are emerging as significant pathogens in the aquaculture industry. Herpes and herpes-like viruses have been reported in a variety of commercially important oyster species of the genera Crassostrea (Farley et al. 1972, Hine et al. 1992, Burge et al. 2011, Lynch et al. 2012) and Ostrea (Hine \& Thorne 1997, Hine et al. 1998, da Silva et al. 2008), as well as in the scallops 
Pecten maximus and Chlamys farreri (Arzul et al. 2001a, Tang et al. 2010), clams Ruditapes spp. (Arzul et al. 2001c) and abalone Haliotis spp. (Tan et al. 2008, Savin et al. 2010). Despite the significant impacts of herpesviruses on molluscan aquaculture, ostreid herpesvirus (OsHV) is one of only 3 molluscan herpesviruses (family Malacoherpesviridae) that have been characterised at the molecular level (Davison et al. 2009, Savin et al. 2010); the others being abalone ganglioneuritis virus from Haliotis spp. (Savin et al. 2010) and acute viral necrobiotic virus (AVNV) from the Chinese scallop Chlamys farreri (Tang et al. 2010). Phylogenetic comparisons indicate that AVNV and OsHV are variants of the same virus (Renault et al. 2012). OsHV is known to cause severe mortality events in the Pacific oyster C. gigas; however, molecular analyses of hatchery-reared $O$. edulis and Ruditapes spp. (Arzul et al. 2001c), as well as samples derived from experimental transmission trials (Arzul et al. 2001b), indicate that OsHV Type 1 (OsHV-1) can infect a range of bivalve hosts. Spat and juvenile C. gigas infected with OsHV appear to be particularly susceptible to mortality, with adults less severely affected or asymptomatic (Arzul et al. 2002). As C. gigas represents over $95 \%$ of the world's cultured oyster production, estimated at $661500 \mathrm{t}$ and US\$1.3 billion in 2010 (FAO 2013), OsHV represents a significant risk globally to commercial bivalve production.

Several studies conducted in France (Le Deuff et al. 1996, Sauvage et al. 2009), Ireland (Malham et al. 2009, Cotter et al. 2010) and the United States (Friedman et al. 2005, Burge et al. 2006) strongly suggest a role for environmental stress in OsHV outbreaks. Specifically, OsHV outbreaks appear to be related to both increases in water temperature $\left(>16^{\circ} \mathrm{C}\right)$ and intensive farming (Pernet et al. 2012). In some cases, OsHV mortality events have also been linked to the presence of Vibrio species including $V$. harveyi, $V$. splendidus and $V$. aestuarianus (Segarra et al. 2010). Particularly severe Crassostrea gigas mortalities reported in France, the United Kingdom and the Republic of Ireland in 2008 to 2009 were associated with the presence of an OsHV-1 variant known as the microvariant ( $\mu$-var) (Segarra et al. 2010). However, recent studies demonstrate that OsHV-1 $\mu$-var can also be detected in asymptomatic oysters, possibly reflecting latent infection or a low viral load (Dundon et al. 2011).

Mortality events in which OsHV has been definitively identified as the causative agent have previously been confined in the northern hemisphere, with outbreaks in Europe (da Silva et al. 2008,
Sauvage et al. 2009, Segarra et al. 2010), the United States (Friedman et al. 2005, Burge et al. 2006) and Mexico (Vásquez-Yeomans et al. 2010). Herpes-like virus particles have been observed in moribund Crassostrea gigas and Ostrea chilensis in New Zealand (Hine et al. 1992, 1998), in Bonamia-infected O. angasi (Hine \& Thorne 1997) and in hatcheryreared Saccostrea glomerata larvae experiencing mortalities (M. Hine pers. comm.) in Australia. Due to a lack of molecular data, it is unclear whether OsHV was the viral agent in these cases; however, the herpesvirus-like particles described in $O$. angasi appeared to be ultrastructurally distinct from those described in C. gigas (Hine \& Thorne 1997).

While Crassostrea gigas is not native to Australia, it has become the major commercial oyster in Tasmania and South Australia and is preferentially farmed in some New South Wales (NSW) estuaries due to the impact of QX disease (infection with Marteilia sydneyi) on the indigenous species Saccostrea glomerata. In the Georges River, NSW, triploid C. gigas are farmed alongside $S$. glomerata, while in the Parramatta River (Sydney Harbour), only wild populations of diploid C. gigas and S. glomerata are present; with C. gigas considered an invasive pest species. Triploid C. gigas culture commenced in the Georges River in 2004 , and it generally takes approximately 7 to $18 \mathrm{mo}$ to grow small spat (shell height: $4 \mathrm{~mm}$ ) to a marketable size (shell height: 50 to $120 \mathrm{~mm}$ ).

In the summer of 2010, mortalities of $>95 \%$ were observed in both wild (diploid) and farmed (triploid) Crassostrea gigas in the Georges River, and in wild populations of diploid C. gigas in the Parramatta River. Subsequent testing revealed that the mortalities were caused by OsHV-1 $\mu$-var, the first confirmed case in Australian oysters.

\section{MATERIALS AND METHODS}

\section{Oyster cultivation, chronology of events and study sites}

Triploid Crassostrea gigas cultivated at Woolooware Bay, Georges River, were all from the same broodstock population and were sourced from either the Port Stephens or the Tasmanian hatchery. Prior studies indicate that there is a high genetic diversity within both Australian and NSW C. gigas stocks (Miller et al. 2012). Diploid C. gigas are considered a pest in NSW and are also known to have been present in the Georges River since 1984. C. gigas is not cultivated in the Parramatta River; therefore, samples 
collected from this estuary constituted diploid oysters from wild populations. Records indicate that diploid C. gigas have been present in the Sydney area since the late 1960s (for $>10$ generations). Inter-estuarine movements of farmed oysters, including diploid and triploid C. gigas, as well as Saccostrea glomerata, are regulated in NSW.

Investigations of unexplained mortalities in triploid and diploid Crassostrea gigas were conducted at 3 oyster leases located in Woolooware and Quibray Bays in the Georges River and 4 sites within the Parramatta River (Fig. 1). Key dates and the types and number of samples collected from each estuary are summarised in Table 1. C. gigas and Saccostrea glomerata samples collected from the Georges River were cultivated in trays according to standard industry practice and at standard growing height (Smith et al. 2000); however, floating baskets and trays on the substratum were also in use at the time of the study. As poor water quality was considered a potential cause of the initial Woolooware Bay mortalities, water samples were also collected for toxicological analysis (Table 1). No prior screening for OsHV-1 had been carried out on samples from either the Georges or Parramatta Rivers.

\section{Sampling of oysters}

Oyster samples from mortality events were collected in accordance with NSW Department of Primary Industries (DPI) fish kill policy (NSW DPI 2011). Oysters from cultivation areas were submitted directly to NSW DPI for testing, while field personnel were deployed to identify evidence of disease or mortality of wild oysters. Samples of farmed oysters were collected from trays, and wild oysters were detached from the substratum. Each sample was enclosed in an individual zip lock plastic bag and transported to the laboratory on ice. In the case of mortality events, live oysters adjacent to areas showing evidence of disease were selected preferentially to provide suitable diagnostic samples. Surviving triploid Crassostrea gigas from Lease 1 (Fig. 1) were sampled approximately 12 and 26 wk after the outbreak (Table 1). For the purpose of testing for continued transmission of OsHV-1, naïve, triploid C. gigas (sentinel oysters, $60 \mathrm{~mm}$ shell height) were translocated from the Hawkesbury River to sites in Woolooware Bay and Quibray Bay (Table 1). Oysters were placed in a basket at normal commercial tray growing height on 6 January 2011.

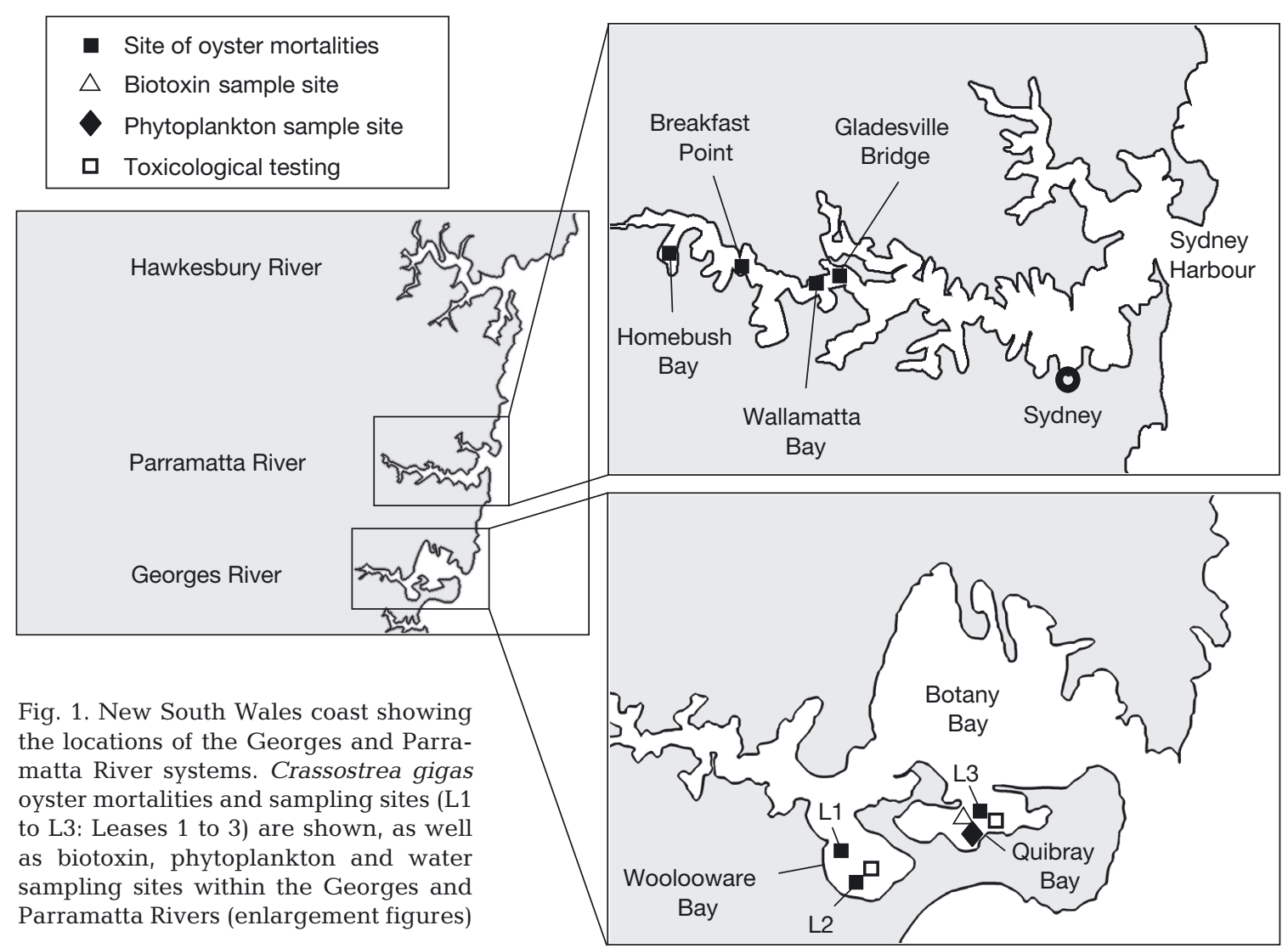




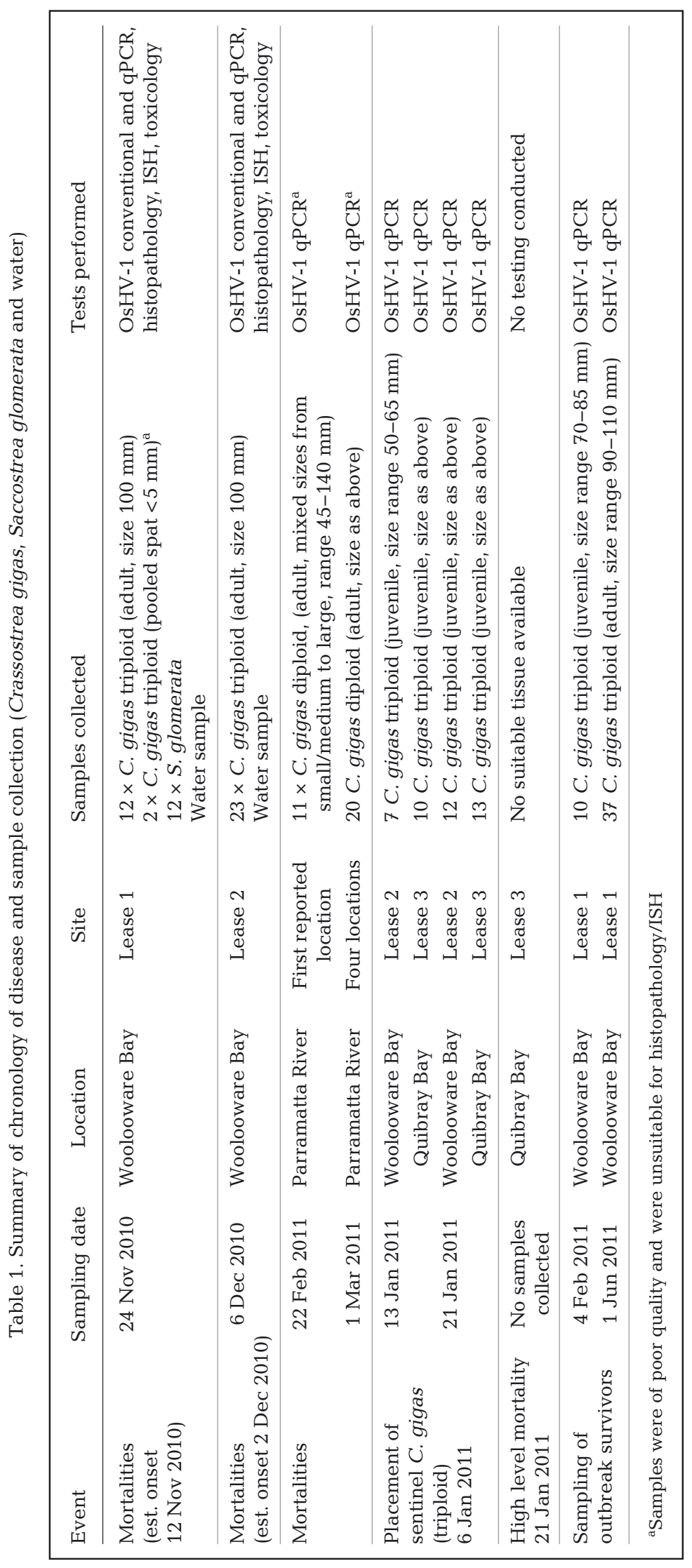

\section{Collection of environmental data}

Water samples were collected from Woolooware Bay and Quibray Bay on 2 separate occasions (Table 1) and were submitted to the Department of Environment, Climate Change and Water (DECCW) Environmental Forensics and Analytical Science Laboratories (EFAS) (Lidcombe, NSW) to test for potential pollutants, including organochlorine pesticides, organophosphate pesticides and metals. Water samples for the assessment of harmful phytoplankton species and oyster samples for shellfish biotoxin analyses were collected at regular intervals by a representative of the NSW Food Authority (Newington, NSW) during routine food safety testing in Quibray Bay, adjacent to Woolooware Bay. Shellfish biotoxins were analysed in presence/ absence assays and included domoic acid, saxitoxin and okadaic acid (amnesic, paralytic and diarrhetic shellfish toxin, respectively). Only limited water temperature data were available for Woolooware Bay in 2010; however, historical data collected from Woolooware Bay and the adjacent Quibray Bay are highly congruent, and therefore, where necessary, data from Quibray Bay was used. Daily rainfall data were obtained from the Australian Bureau of Meteorology (BOM) website (BOM 2010) for a station approximately $5 \mathrm{~km}$ distant from Woolooware Bay. Intermittent (approximately twice monthly) rainfall data were also collected from rain gauges in Quibray Bay during visits from food safety officers and were used to confirm the local accuracy of the BOM data. Salinity data were also collected at these times from Quibray Bay, and occasional readings (approximately monthly) were also taken from Woolooware Bay intake water.

\section{Sample processing}

Upon receipt, the external surfaces of the oysters were scrubbed to remove excess mud and debris and the oysters were opened using a sterile shucking knife. Individual disposable scalpel blades were used 
to sever the adductor muscles and to transfer the oysters to sterile petri dishes for dissection. Oysters were examined for any gross pathology, and transverse sections containing gill, mantle, gonad and digestive gland were taken for preservation in $100 \%$ ethanol (for molecular testing) and neutral-buffered formalin (for histological analysis). For histology, formalinfixed tissues (24 to $48 \mathrm{~h}$ fixation) were embedded in paraffin, sectioned $(5 \mu \mathrm{m})$ and stained with haematoxylin and eosin. For molecular testing, approximately $1 \times 5 \mathrm{mg}$ mantle and $1 \times 5 \mathrm{mg}$ gill tissue were dissected from each oyster and pooled in a sterile microcentrifuge tube. Initial molecular diagnostic testing was performed using DNA extracted with the Qiagen DNeasy Blood and Tissue kit, according to the manufacturer's instructions. For subsequent high-throughput testing, tissue pools were digested by the addition of $180 \mu \mathrm{l}$ ATL buffer and $20 \mu \mathrm{l}$ of Proteinase $\mathrm{K}$ (Qiagen) with incubation at $56^{\circ} \mathrm{C}$ for 3 to $14 \mathrm{~h}$. After digestion, the samples were mixed vigorously with a vortex mixer for $30 \mathrm{~s}$ and then centrifuged at $3000 \times g$ for $5 \mathrm{~min}$. Nucleic acids were purified from $25 \mu \mathrm{l}$ of the supernatant using the MagMax-96 $6^{\mathrm{TM}}$ Viral RNA Isolation Kit (Applied Biosystems), according to the manufacturer's directions, with a Kingfisher-96 magnetic particle handling system (Thermo) using the AM1836 DW-standard program supplied for the MagMax-96 ${ }^{\mathrm{TM}}$ kit (Applied Biosystems). Nucleic acids were eluted in $50 \mu \mathrm{l}$ of elution buffer.

\section{OsHV-1 conventional PCR}

Assays for OsHV-1 were undertaken using 2 separate primer sets (Arzul et al. 2002). The first primer set (B3 and B2) targets an open reading frame of unknown function, while the second primer set (C2 and C6) targets 2 genes of unknown function separated by a microsatellite region (Arzul et al. 2001c, 2002). Reactions were prepared in a total volume of $50 \mu$ l containing $1 \times$ BioTaq buffer, $200 \mu \mathrm{M}$ dNTPs, $2.5 \mathrm{mM} \mathrm{MgCl}_{2}, 400 \mathrm{nM}$ of each primer, $1 \mathrm{U}$ of BioTaq DNA polymerase (Bioline) and $4 \mu \mathrm{l}$ of DNA extract. Cycling parameters for both PCR assays involved a 2 min initial denaturation step at $95^{\circ} \mathrm{C}_{i}$ followed by 35 cycles of denaturation at $95^{\circ} \mathrm{C}$ for $30 \mathrm{~s}$, annealing at $60^{\circ} \mathrm{C}$ for $30 \mathrm{~s}$, and extension at $72^{\circ} \mathrm{C}$ for $1 \mathrm{~min}$; and a final extension step at $72^{\circ} \mathrm{C}$ for $5 \mathrm{~min}$. Reaction products were visualised after electrophoresis in a $1.5 \%$ agarose gel stained with ethidium bromide. Products of the appropriate size (approximately 700 base pairs [bp]) were excised from the gel, and DNA was recovered using the QIAquick Gel Extraction Kit (Qiagen). Nucleotide sequencing reactions were prepared in duplicate using the $\mathrm{C} 2$ and $\mathrm{C} 6$ primers and performed at the Australian Genome Research Facility using BigDye terminator Version 3.1 (Applied Biosystems).

\section{Sequence analysis}

OsHV-1 sequences (C2/C6 region) derived from this study were aligned with representative strains from other outbreaks using ClustalW (Larkin et al. 2007). Genbank accession numbers of the sequences used in the alignment were as follows: New Zealand 2010 (JN800131), Japan 2010 (JN800133), USA 2007 (JN800128), Ireland 2009 (JN800129), China 2002 (JN800132), France 2010 Isolate 2 (JN800131), France 2010 Isolate 12 (JN800122), France 2010 Isolate 13 (JN800123), France 2008 u-var (HQ842610), France 2005 Isolate 1 (JN800081), France 2003 Isolate 1 (JN800075), France 2003 Isolate 3 (JN800076), France 1995 Isolate 20 (JN800072), France OsHV-1 reference type (AY509253) and acute viral necrobiotic virus (AVNV; GQ153938). GeneDoc was used for alignment display (Nicholas et al. 1997). To establish the phylogeny of the Australian OsHV-1 strain, a maximum likelihood approach with 1000 bootstrap replications was employed within the Molecular Evolutionary Genetics Analysis package (MEGA V5.1) (Tamura et al. 2011).

\section{Quantitative PCR (qPCR) assays}

Two assays with hydrolysis probe detection chemistry were used to detect targets in the B (Martenot et al. 2010) and $C$ regions of the OsHV-1 genome (Table 2). Reactions were prepared in a $25 \mu \mathrm{l}$ volume using the AgPath-IDTM One-Step RT-PCR Kit (Life Technologies) with $200 \mathrm{nM}$ primers, $100 \mathrm{nM}$ probe and $5 \mu$ of purified nucleic acids. Thermocycling and fluorescent data acquisition were performed using an ABI 7500 Real-Time PCR machine (Applied Biosystems), with the following parameters: $95^{\circ} \mathrm{C}$ for 10 min followed by 45 cycles of $95^{\circ} \mathrm{C}$ for $15 \mathrm{~s}$ and $60^{\circ} \mathrm{C}$ for $45 \mathrm{~s}$. The 6-carboxyfluorescin (FAM) fluorescence signal acquired at the end of the annealing/ extension phase of each cycle was normalised to the signal from the ROX (6-Carboxyl-X-Rhodamine) passive reference dye and corrected for baseline fluorescence calculated according to a proprietary algorithm (ABI 7500 software, Applied Biosystems). 
Table 2. PCR primers and probes used in this study

\begin{tabular}{|c|c|c|c|c|}
\hline Assay name & $\begin{array}{l}\text { Primer/ } \\
\text { probe name }\end{array}$ & Sequence $\left(5^{\prime}-3^{\prime}\right)$ & $\begin{array}{l}\text { Genome } \\
\text { region }\end{array}$ & Source \\
\hline \multicolumn{5}{|c|}{ Conventional PCR } \\
\hline $\mathrm{C} 2 / \mathrm{C} 6$ & $\begin{array}{l}\mathrm{C} 2 \\
\mathrm{C} 6\end{array}$ & $\begin{array}{l}\text { CTC TTT ACC ATG AAG ATA CCC ACC } \\
\text { GTG CAC GGC TTA CCA TTT TT }\end{array}$ & $\mathrm{C}$ region & $\begin{array}{l}\text { Arzul et al. } \\
(2002)\end{array}$ \\
\hline B3/B2 & $\begin{array}{l}\text { B3 } \\
\text { B2 }\end{array}$ & $\begin{array}{l}\text { GTG GAG GTG GCT GTT GAA AT } \\
\text { CAA CAG CTT TGG AGG TTG GT }\end{array}$ & $\mathrm{B}$ region & $\begin{array}{l}\text { Arzul et al. } \\
(2002)\end{array}$ \\
\hline \multicolumn{5}{|c|}{ Quantitative PCR } \\
\hline OsHV-1CR & $\begin{array}{l}\text { OsHV-1CRF } \\
\text { OsHV-1CRR } \\
\text { OsHV-1CR probe }\end{array}$ & $\begin{array}{l}\text { CGT TTT ATC CAC CAC GAT TTT TAT T } \\
\text { TAC ATC AAA CCC ACT TTT CCT ATG AT } \\
\text { FAM-CAC TCA TGA AAA CAC CGC TAA G. }\end{array}$ & $\begin{array}{l}\text { C region } \\
\text { BHQ-1 }\end{array}$ & $\begin{array}{l}\text { X. Gu et al. } \\
\text { (unpubl.) }\end{array}$ \\
\hline OsHV-1B & $\begin{array}{l}\text { OsHV1BF } \\
\text { B4 } \\
\text { B probe }\end{array}$ & $\begin{array}{l}\text { GTC GCA TCT TTG GAT TTA ACA A } \\
\text { ACT GGG ATC CGA CTG ACA AC } \\
\text { FAM-TGC CCC TGT CAT CTT GAG GTA TA }\end{array}$ & $\begin{array}{l}\text { B region } \\
\text { HQ-1 }\end{array}$ & $\begin{array}{l}\text { Martenot et } \\
\text { al. (2010) }\end{array}$ \\
\hline
\end{tabular}

Samples were considered negative if the ROXnormalised, baseline-corrected FAM fluorescence $(\Delta \mathrm{Rn})$ remained $<0.05$. A cycle-threshold $(\mathrm{Ct})$ value was assigned for samples in which there was a logarithmic increase in fluorescence, defined as the cycle at which $\Delta \mathrm{Rn}$ first exceeded the fluorescence threshold of 0.05. Each test plate included the following control reactions: no template (nuclease-free water), extraction control (20 ng tRNA [transfer ribonucleic acid, from baker's yeast; Sigma] in nuclease-free water, included during nucleic acid purification) and positive control preparations. The latter were prepared from gill and mantle tissue digests, diluted 1:10 $000(\mathrm{v} / \mathrm{v})$ in phosphate-buffered gelatin saline to give $\mathrm{Ct}$ values of approximately 29 and 32, and stored at $-80^{\circ} \mathrm{C}$ as single-use aliquots.

\section{Statistical analyses}

DNA samples that were negative (undetermined $\mathrm{Ct}$ values) were excluded from the analysis and a D'Agostino and Pearson normality test was conducted on the Ct data prior to analysis. Mean Ct values derived from Crassostrea gigas and Saccostrea glomerata samples collected from Lease 1 were analysed using a 2-tailed $t$-test. One-way analysis of variation (ANOVA) employing Tukey's multiple comparison test was used to compare mean $\mathrm{Ct}$ values from triploid C. gigas collected during the Woolooware Bay outbreak, from surviving oysters collected 10 and 26 wk post-outbreak, from diploid C. gigas collected from the Parramatta River and from sentinel oysters collected 1 and 2 wk post-placement in Woolooware and Quibray Bays.

\section{Vibrio harveyi PCR}

As some prior studies on OsHV-1 have suggested that there may be a relationship between severe mortality events associated with OsHV-1 and the presence of Vibrio spp., including $V$. harveyi (Segarra et al. 2010), we tested Crassostrea gigas and Saccostrea glomerata samples collected during the outbreak in Woolooware Bay together with S. glomerata samples that had been collected some weeks prior from the neighbouring Quibray Bay. A modification of a previously published assay targeting the ToxR gene (Pang et al. 2006) was used for the detection of $V$. harveyi in the Woolooware Bay oyster samples. Briefly, reactions contained $1 \times$ BioTaq buffer, $2 \mathrm{mM} \mathrm{MgCl}_{2}$, $0.2 \mathrm{mM}$ dNTPs, $0.4 \mu \mathrm{M}$ primers (ToxRF1: 5'-GAA GCA GCA CTC ACC GAT-3'; ToxRR1: 5'-GGT GAA GAC TCA TCA GCA-3'), 1 U of BioTaq polymerase (Bioline) and $2 \mu \mathrm{l}$ of DNA template in a total volume of $25 \mu \mathrm{l}$. Cycling parameters were optimised for use on a BioRad Optimus thermal cycler and were as follows: 1 cycle of denaturation at $94^{\circ} \mathrm{C}$ for $3 \mathrm{~min}$; 35 cycles of denaturation $\left(94^{\circ} \mathrm{C}, 1 \mathrm{~min}\right)$, annealing $\left(63^{\circ} \mathrm{C}, 1 \mathrm{~min}\right)$ and extension $\left(72^{\circ} \mathrm{C}, 1 \mathrm{~min}\right)$; and final extension at $72^{\circ} \mathrm{C}$ for $5 \mathrm{~min}$. Total DNA extracted from an oyster sample positive for $V$. harveyi was used as a positive control template. PCR products (382 bp) were visualised after electrophoresis on a $1.5 \%$ agarose gel stained with ethidium bromide.

\section{OsHV-1 probe generation and specificity}

For in situ hybridisation (ISH) experiments, a DIG-labelled PCR probe was generated using the 
B3 and B2 primers. PCR was performed as described above, except that dNTPs were replaced with DIG-labelling mix (Roche). Dot blot hybridisation was used to test the probe for cross-reactivity against purified Crassostrea gigas and Saccostrea glomerata DNA. Purified OsHV-1 PCR product generated using the B3/B2 primer set was used as a positive control. Of 2-fold serial dilutions of the

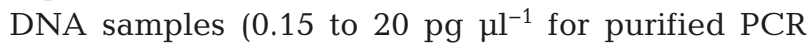

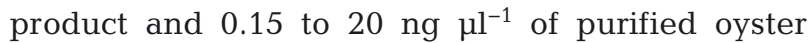
DNA) $20 \mu \mathrm{l}$ was boiled, chilled and then spotted onto a nylon membrane using a dot blot manifold. DNA was ultraviolet cross-linked to the membrane, prehybridised in DIG EasyHyb buffer (Roche) for $1 \mathrm{~h}$ at $42^{\circ} \mathrm{C}$ and hybridised at $42^{\circ} \mathrm{C}$ overnight in a roll tube. The hybridisation solution consisted of $12.5 \mathrm{ng} \mathrm{ml}^{-1}$ pre-boiled probe diluted in DIG EasyHyb buffer. After hybridisation, the membrane was washed $2 \times 15$ min with $2 \times$ sodium citrate buffer (SSC)-0.1\% sodium dodecyl sulphate (SDS), followed by $2 \times 15$ min washes in $0.5 \times \mathrm{SSC}-0.1 \%$ SDS at $42^{\circ} \mathrm{C}$. The membrane was then blocked for $30 \mathrm{~min}$ and reacted with alkaline phosphataseconjugated anti-DIG diluted to 1:500 in blocking solution (Roche). The membrane was washed $2 \times$ 15 min with washing buffer $(0.1 \mathrm{M}$ maleic acid, $0.15 \mathrm{M} \mathrm{NaCl}, 0.3 \%$ Tween 20 ) and detected with NBT-BCIP solution (Sigma Aldrich).

\section{In situ hybridisation}

Sections of oyster tissue approximately $5 \mu \mathrm{m}$ thick were cut from paraffin blocks, placed on Superfrost Plus slides (Menzel Gläser) and air dried. Slides were dewaxed in xylene and rehydrated in an ethanol series and then treated with $100 \mu \mathrm{l}$ of $10 \mu \mathrm{g} \mathrm{ml}^{-1}$ Proteinase $\mathrm{K}$ for $30 \mathrm{~min}$ at $37^{\circ} \mathrm{C}$ in a humid chamber. Sections were washed with Tris buffer $(0.1 \mathrm{M}, \mathrm{pH} 8.0)$ for $3 \mathrm{~min}$ and prehybridised for $1 \mathrm{~h}$ at $37^{\circ} \mathrm{C}$ in $100 \mu \mathrm{l}$ prehybridisation buffer $\left(50 \%\right.$ formamide, $4 \times \mathrm{SSC}_{1} 1 \times$ Denhardt's solution, $0.25 \mathrm{mg}$ yeast tRNA ml${ }^{-1}, 10 \%$ dextran sulfate). Prehybridisation buffer was exchanged for $100 \mu$ hybridisation solution (same as prehybridisation solution but with $5 \mathrm{ng} \mathrm{hl}^{-1}$ of probe added), and slides were covered with hybridisation coverslips (ProSiTech) and heated to $95^{\circ} \mathrm{C}$ for $5 \mathrm{~min}$ on a dry heating block. Slides were cooled on ice for 5 min and then incubated overnight in a humid chamber in a Hoefer Red Roller hybridisation oven (Hoefer) at $42^{\circ} \mathrm{C}$. The following day, slides were washed in wash buffer (Roche) at $40^{\circ} \mathrm{C}$ for $10 \mathrm{~min}$.
Sections were then blocked with $500 \mu \mathrm{l}$ of DIG blocking solution (Roche) at room temperature (RT) for $30 \mathrm{~min}$. Blocking solution was exchanged for a 1:200 solution of anti-DIG antibody (Roche) in blocking buffer, and sections were incubated at RT for $1 \mathrm{~h}$. Excess antibody was removed with a 30 min wash in $1 \times$ wash buffer (Roche) at RT. Sections were equilibrated for $5 \mathrm{~min}$ in detection buffer (Roche) and then incubated with $500 \mu \mathrm{l}$ BCIP/NBT in the dark at RT for $4 \mathrm{~h}$. Following development, slides were rinsed twice in tap water and air dried.

\section{RESULTS}

\section{Field observations}

Stocks of triploid Crassostrea gigas cultivated at 2 separate leases (Fig. 1) in Woolooware Bay, Georges River (NSW, Australia), as well as wild diploid C. gigas in the same estuary, experienced $>95 \%$ mortality during the early summer (November and December) of 2010. Aside from the affected stock, there had been no introductions of triploid C. gigas to the Georges River from other sources for a period of 12 mo prior to the outbreak. The stock introduced to the estuary in November of 2010 was found to be negative for OsHV-1 on subsequent testing (authors' unpubl. data). Sentinel oysters did not experience any mortalities at their site of origin (Hawkesbury River) prior to translocation to the Georges River and were found to be negative for OsHV-1 during subsequent surveillance studies (B. Moloney et al. unpubl. data). Mortalities in the Georges River were observed in oysters with shell heights of 4 to $120 \mathrm{~mm}$, comprising spat, juvenile and adult triploid C. gigas, while neighbouring Saccostrea glomerata appeared unaffected. Oysters at both leases had been in good health previously; however, just prior to the first observed mortalities (in November) at Lease 1, a plume of discoloured water and an algal bloom were observed in the vicinity of the affected oysters. Within 1 wk of the environmental disturbances, deaths were observed in $C$. gigas oyster stocks at Lease 1. C. gigas mortalities were also recorded in December at Lease 2 (Fig. 1) in Woolooware Bay. At this time, oyster movements were restricted to within the estuary. Macroscopic examination of these oysters revealed that the oyster shells and tissues were visibly coated in algae. The oysters were found to be moribund, with stiff and unresponsive tissues. The small proportion of C. gigas which survived the out- 

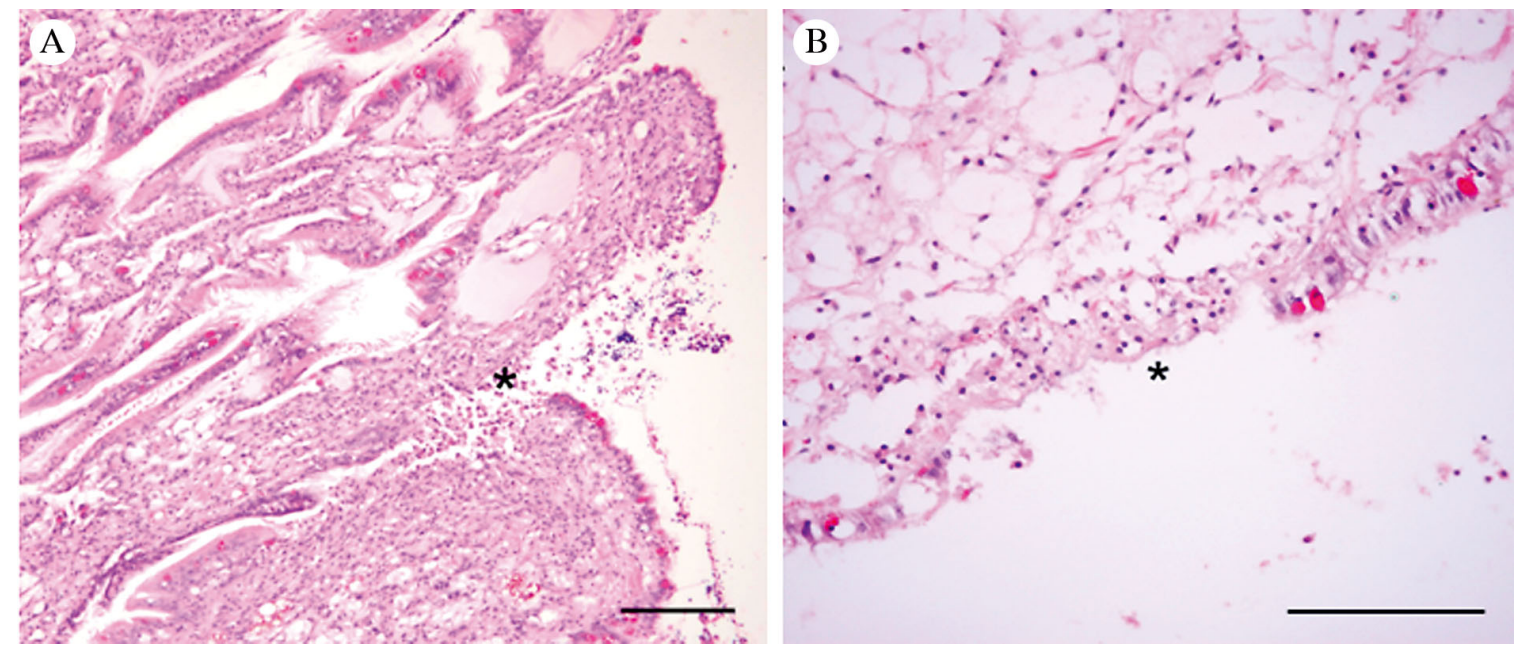

Fig. 2. Crassostrea gigas. Photomicrographs of haemotoxylin and eosin-stained sections of surviving C. gigas specimens collected during the mortality events at (A) Lease 1 and (B) Lease 2, showing multifocal ulceration (stars) with focal underlying accumulations of haemocytes on palp (A) and gill (B) epithelium. Scale bars $=100 \mu \mathrm{m}$

break at Lease 2 had grown according to expectations when observed in June of 2011, approximately 6 mo after the start of the outbreak.

Approximately 50 naïve sentinel triploid Crassostrea gigas, placed at the site of the first outbreak (Lease 1) in Woolooware Bay and at Lease 3 in Quibray Bay on 6 January of 2011 experienced $>50 \%$ mortality within 1 wk of translocation (Table 1). Approximately $2 \mathrm{wk}$ post-placement, all of the sentinels had died. Subsequently, on 25 January 2011, a mortality approaching $100 \%$ was reported in the farmed C. gigas population in Quibray Bay. Due to advanced tissue degradation, no samples were collected for testing.

Mortalities in wild diploid Crassostrea gigas in the Parramatta River were first detected on 22 February 2011, but the time of onset of the outbreak was not known because of the absence of commercial production in this waterway. An anecdotal report from the public suggested a mortality event might have commenced up to 4 mo prior. Consequently, it was not possible to access archival environmental data relevant to the initial outbreak. Inspections at 4 sites, Gladesville Bridge, Wallamatta Bay, Breakfast Point and Homebush Bay, (Fig. 1) on 22 February 2011 indicated a mortality rate in C. gigas of between 50 and $100 \%$. Surviving C. gigas were in poor condition. The presence of many empty shells and the previously mentioned anecdotal report suggest that the mortalities may have begun many weeks before samples were taken. There were no apparent mortalities in wild Saccostrea glomerata in these locations.

\section{Histopathology}

In all oysters that were examined, there was nodular to diffuse infiltration of the leydig tissue with haemocytes, often concentrated around epithelia (gut, digestive gland and mantle), with diapedesis of haemocytes evident across digestive gland epithelia. Leydig tissue was granular, hypereosinophilic or collapsed in all oysters examined, with the severity varying from mild (Saccostrea glomerata) to moderate or severe (Crassostrea gigas). Examination of mantle, palp and gill epithelium (Fig. 2A) demonstrated multifocal erosive and focally extensive ulcerative lesions in C. gigas only. Remnant contiguous epithelium was often fragmented or degenerate, with pyknotic nuclei (Fig. 2B). Underlying haemocytic infiltrates were mild to moderate and consisted of scattered haemocytes with small round nuclei and minimal eosinophilic cytoplasm. These changes were not observed in examined specimens of $S$. glomerata. Cowdry Type A intranuclear inclusion bodies (marginated chromatin and central eosinophilic nuclear inclusions), sometimes associated with OsHV-1 infection (da Silva et al. 2008), were not observed in any oysters examined.

\section{Molecular detection of OsHV-1}

All Crassostrea gigas oyster samples (up to $18 \mathrm{mo}$ of age) collected from Woolooware Bay during the initial outbreak yielded amplicons in the 2 conventional PCR assays for OsHV-1 (Fig. 3A,B). Similarly, Saccostrea glomerata (12 samples) collected adjacent 
A

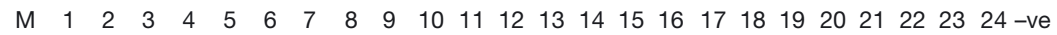

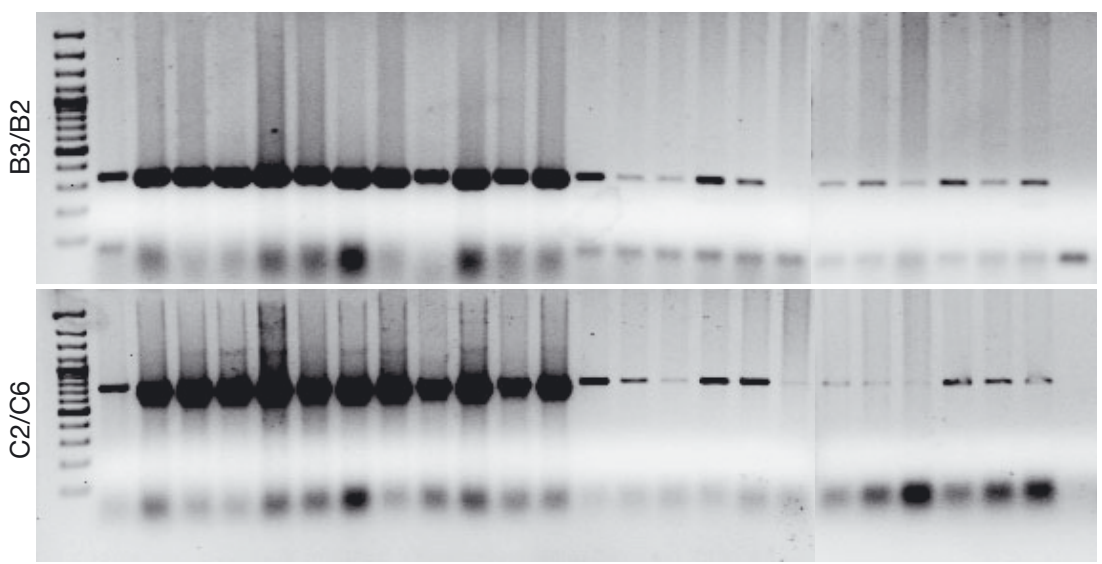

B

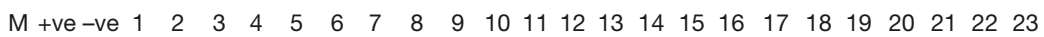

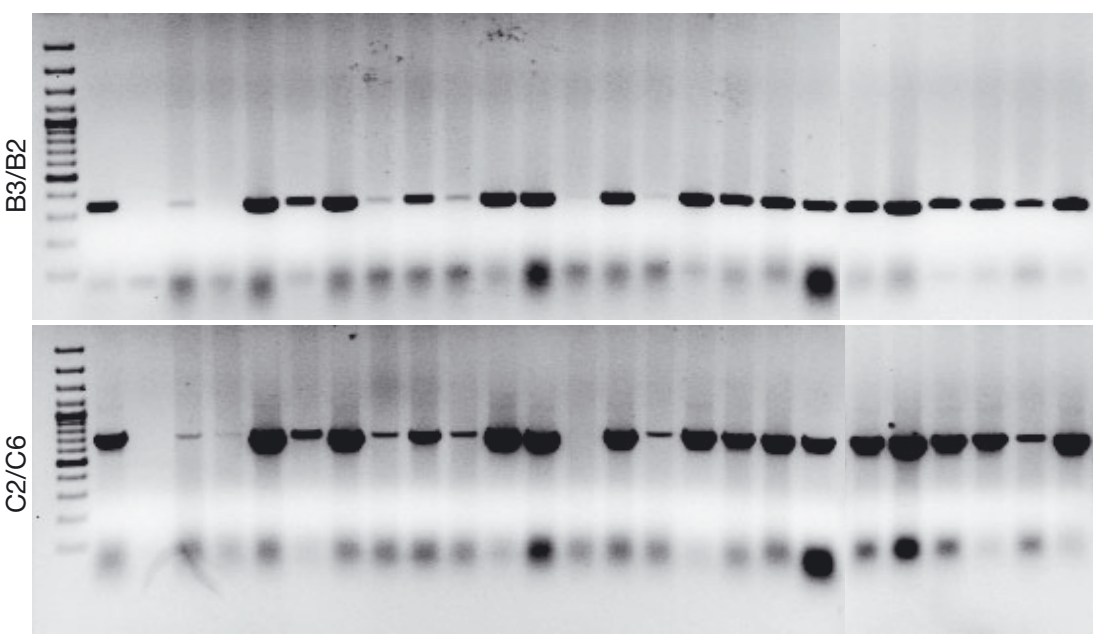

Fig. 3. (A, B) PCR amplicons derived from DNA extracts of oysters collected at Lease 1 (A) and Lease 2 (B) in Woolooware Bay, obtained using the B3/B2 and C2/C6 primer pairs. In (A), Samples 1 to 12 are $C$. gigas amplicons and Samples 13 to 24 are the (much weaker) $S$. glomerata amplicons. Amplicons from $C$. gigas and $S$. glomerata were subsequently sequenced to verify their identity as ostreid herpesvirus-1 (OsHV-1) DNA. In (B), Samples 1 to 23 are all amplicons derived from $C$. gigas. M: 100 bp ladder (Fermentas); -ve: negative (no template) control ${ }_{i}+\mathrm{ve}$ : positive control. (C) Comparison of the mean and range of $\mathrm{Ct}$ values derived from $\mathrm{qPCR}$ performed on $C$. gigas and S. glomerata collected from Lease 1 . The means are statistically different (2-tailed, $\mathrm{p}<0.0001)$. (D) Comparison of mean qPCR $\mathrm{Ct}$ values derived from triploid (Tr) C. gigas collected from Leases 1 and 2 during the initial Woolooware Bay outbreak with those from positive triploid sentinel oysters (1 and 2 wk post-deployment in Woolooware [WB] and Quibray Bays [QB]) and surviving oysters (12 and 26 wk following the initial outbreak). The $\mathrm{Ct}$ values derived from qPCR testing of diploid (Di) C. gigas collected during the Parramatta River (PR) outbreak are also compared. Different lower case letters indicate groups that are statistically different at the $\mathrm{p}<0.01$ level. Oysters testing negative for OsHV-1 were not included in statistical analyses

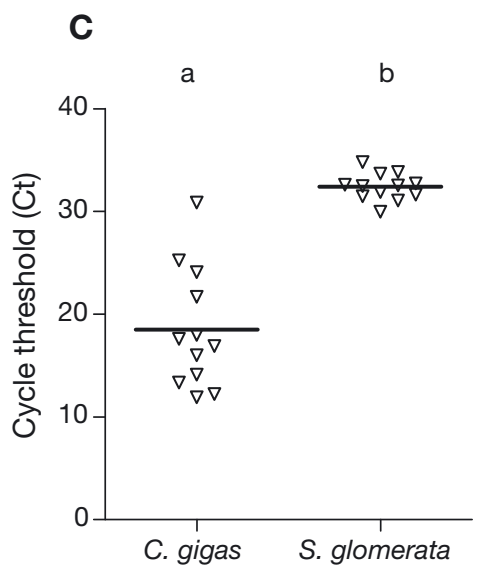

D

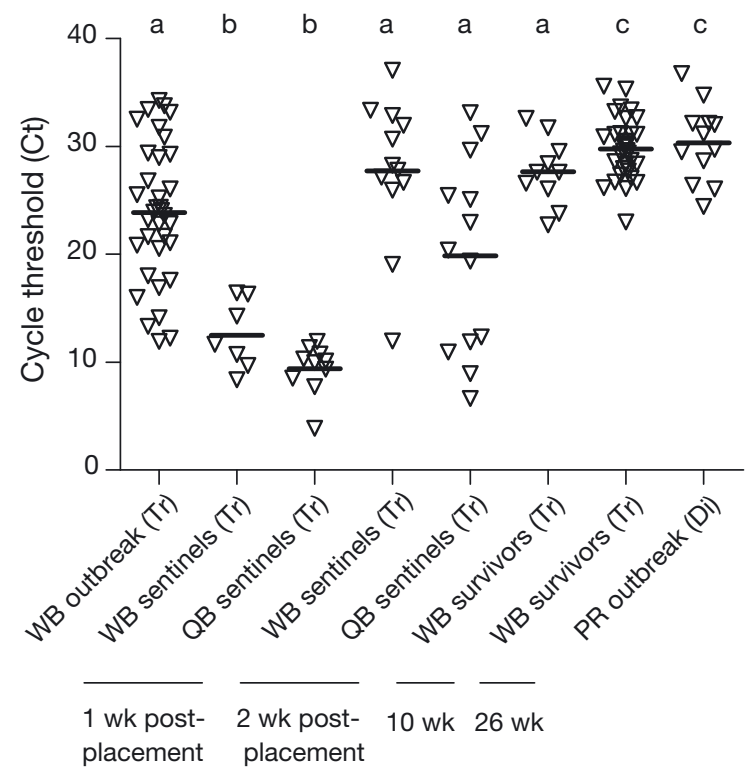


to the C. gigas were positive in both PCR assays, but discernibly less DNA was amplified from these samples (Fig. 3A, Lanes 13 to 24).

$\mathrm{Ct}$ values derived from the qPCR assays were analysed statistically. Data within most groups passed the normality test ( $\mathrm{p}>0.05)$, indicating that the data did not deviate significantly from a normal distribution. The only exception was the data from the $1 \mathrm{wk}$ post-placement sentinels from Quibray Bay; however, inclusion of this group in subsequent ANOVA analysis was deemed valid given that the group had a low sample number (potentially explaining the lack of normality) and given that ANOVA is considered robust regardless of normality (Schmider et al. 2010). A 2-tailed $t$-test indicated that the Ct values were statistically much lower (quantity of OsHV-1 DNA was higher) in Crassostrea gigas compared to the Saccostrea glomerata collected from Woolooware Bay ( $p<0.0001$; Fig. 3C). Although there was no tissue suitable for testing when $100 \%$ mortality was detected in the farmed C. gigas, the presence of OsHV1 in Quibray Bay was confirmed in sentinel oysters tested in the preceding weeks. The qPCR results showed high levels of OsHV-1 in sentinel oysters within 1 wk of placement in both Quibray and Woolooware Bays. The viral load in sentinel oysters from both locations was significantly higher after 1 wk of exposure than after 2 wk of exposure ( $\mathrm{p}<$ 0.01 ) and was also significantly higher than in oysters sampled during the initial outbreak in Woolooware Bay ( $p<0.01$; Fig. 3D). Conversely, the mean $\mathrm{Ct}$ of sentinel oysters sampled after 2 wk of exposure was not statistically different from oysters sampled during the initial outbreak ( $\mathrm{p}>0.05$; Fig. 3D). Triploid C. gigas survivors from Woolooware Bay had a high prevalence of infection $12 \mathrm{wk}$ (10/10 positive) and 26 wk (35/37 positive) after the mortality event, but the viral load was significantly lower than in samples collected during the outbreak (Fig. 3D; p < 0.01). OsHV-1 was detected in only $39 \%$ of adult diploid C. gigas sampled during the Parramatta River outbreak and, therefore, was much less prevalent in these oysters than in triploid $C$. gigas sampled from the Georges River. Indeed, only 2 oysters from a total of 124 C. gigas tested from the Georges River (1.6\%) were negative for OsHV-1. A comparison of the mean Ct values of samples from the Parramatta River outbreak indicated that statistically lower quantities of OsHV-1 were present relative to oysters from the Woolooware Bay outbreak ( $p<0.01)$. The mean viral load in the Parramatta River samples was statistically indistinguishable from that found in the $26 \mathrm{wk}$ survivors from Woolooware Bay ( $p>0.05$; Fig. 3D).

\section{Sequence analysis}

OsHV-1 sequences (C2/C6 region) derived from infected Crassostrea gigas collected from Woolooware Bay (Leases 1 and 2) and the Parramatta River, as well as a further sequence derived from OsHV-1 PCR positive Saccostrea glomerata (collected at Lease 1), were identical. When aligned with sequences of OsHV-1 strains derived from different temporal and geographical origins, the Australian sequence (GenBank Accession Number KC685525) was found to contain a deletion in the microsatellite region similar to the microvariant of OsHV-1 (Segarra et al. 2010) (Fig. 4A). However, there were also some nucleotide differences between the 2 sequences (data not shown). A maximum-likelihood analysis of the OsHV-1 C2/C6 region revealed 2 major phylogenetic clusters defined by the reference strain of OsHV-1 (GenBank Accession Number AY509253) and the OsHV-1 microvariant (GenBank Accession Number HQ842610) (Fig. 4B). The Australian OsHV-1 clustered within the microvariant clade and was most similar to samples sequenced from outbreaks in 2010 in New Zealand, Japan and France. As noted previously (Renault et al. 2012), the majority of sequences within the microvariant cluster are derived from samples collected from 2008 onwards. One possible exception to this is an Irish variant (GenBank Accession Number JQ963169) which was identified in C. gigas adults experiencing mortalities in 2003 and 2004. This sequence is not shown in Fig. 4B due to the fact that only a short sequence was available for phylogenetic analysis; however, alignment of the existing sequence indicated that this variant contained only one nucleotide substitution relative to the microvariant (GenBank Accession Number HQ842610). A further exception is the sequence derived from an OsHV-1 outbreak in China in 2002, which also clusters within the microvariant group and, according to Fig. 4B, most closely resembles the ancestral sequence for this cluster. This finding is in contrast to previous results (Renault et al. 2012) which suggested that the 2002 sample from China falls within the OsHV-1 clade containing the reference strain. The sequence of the microsatellite region of this sample also suggests that it belongs to the microvariant cluster (Fig. 4A).

\section{In situ hybridization}

A dot blot performed on DNA extracts from uninfected Crassostrea gigas and Saccostrea glomerata samples and purified OsHV-1 PCR product demon- 
strated that the OsHV-1 probe did not cross-react with oyster tissue, but was able to detect target DNA down to approximately $6 \mathrm{pg}$ (Fig. 5A). ISH was performed on selected $C$. gigas and $S$. glomerata samples to determine whether OsHV-1 was present within the oyster samples collected from Woolooware Bay. No staining was detectable in $S$. glomerata (Fig. 5B); however, in C. gigas samples, the OsHV-1 probe stained regions within a variety of different tissues, indicating that the oysters were actively infected with OsHV-1. Staining within the gonadal tissue was noted in a number of infected C. gigas samples (Fig. 5C). In some samples, staining was most prominent in what appeared to be haemocytes within the connective tissue surrounding the ova (Fig. 5D - no probe added; Fig. 5E - probe added), but not within the ova themselves, while in other samples staining was confined to the ova (Fig. 5F-no probe added; Fig. 5G-probe added).

\section{Detection of Vibrio harveyi in OsHV-1 infected oysters}

Results of the Vibrio harveyi PCR assay indicate that $V$. harveyi was present in 10/12 and 23/23 of the Crassostrea gigas and $12 / 12$ of the Saccostrea glomerata sampled in late November and early December during the Woolooware Bay outbreak. In contrast, $V$. harveyi was not detectable in S. glomerata samples collected from Quibray Bay in either October (0/30) or early November $(0 / 30)$ of 2010 prior to the outbreak (Table 3).

\section{Environmental data}

Around the time of the initial Crassostrea gigas mortalities in Woolooware Bay, a plume of discoloured water and an algal bloom had been observed in the vicinity of the affected leases. Rainfall data confirmed that there had been heavy rainfall approximately $3 \mathrm{~d}$ prior to the onset of both mortality events (Fig. 6A). Water collected for toxico- logical analyses revealed that organic compounds and metals were below the level of detection except for calcium, iron and magnesium which were typical of that environment and unlikely to be acutely toxic. Historical data from Woolooware and Quibray Bays indicate that these sites are of similar salinity and that the salinity is generally high (33 to $35 \mathrm{ppt}$ ) decreasing to 30-32 ppt following rainfall (data not shown). The influx of freshwater from rainfall in early November 2010, just prior to the mortalities, resulted in a modest decrease in the salinity of the water at Quibray Bay to 30.9 ppt (Fig. 6B). A salinity reading from the intake water at Woolooware Bay at this same time point indicated that salinity in this bay was

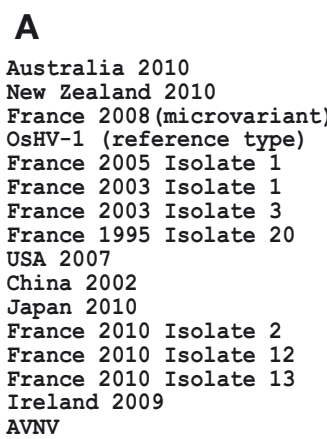

: ACAGCATCTACTACTACTACT--------------GAAAAATGCAGCCTTT : ACAGCATCTACTACTACTACT--------------GAAAAATGCAGCCTTT aCAGCATCTACTACTACTACTACAGCATCTACTACTACTACTACTACTACIACT--GAAAAAATGCAGCCTT ACAGCATCTACTACTACTACTACTACTACTACT----GAAAAAATGCAGCCTTT ACAGCATCTACTACTACTACTACTACTACTACTACTGAAAAAATGCAGCCTTT ACAGCATCTACTACTACTACTACTACTACTACTACTGAAAAAATGCAGCCTTT ACAGCATCTACTACTACTACTACTACTACTACT---GAAAAAATGCAGCCTTT ACAGCATCTACTACTACTACTACTACTACTACTACTGAAAAAATGCAGCCTTT

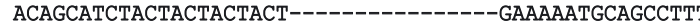

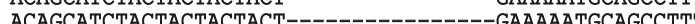
acagcaTCTACTACTACTACT--ACAGCATCTACTACTACTACT---GAAAAATGCAGCCTTT ACAGCATCTACTACTACTACT-------------GAAAAATGCAGCCTTT ACAGCATCTACTACTACTACT------- GAAAAATGCAGCCTTT ACAGCATCTACTACTACTACT--------------GAAAAAATGCAGCCTTT ACAGCATCTACTACTACT----------- GAAAAAATGCAGCCTTT

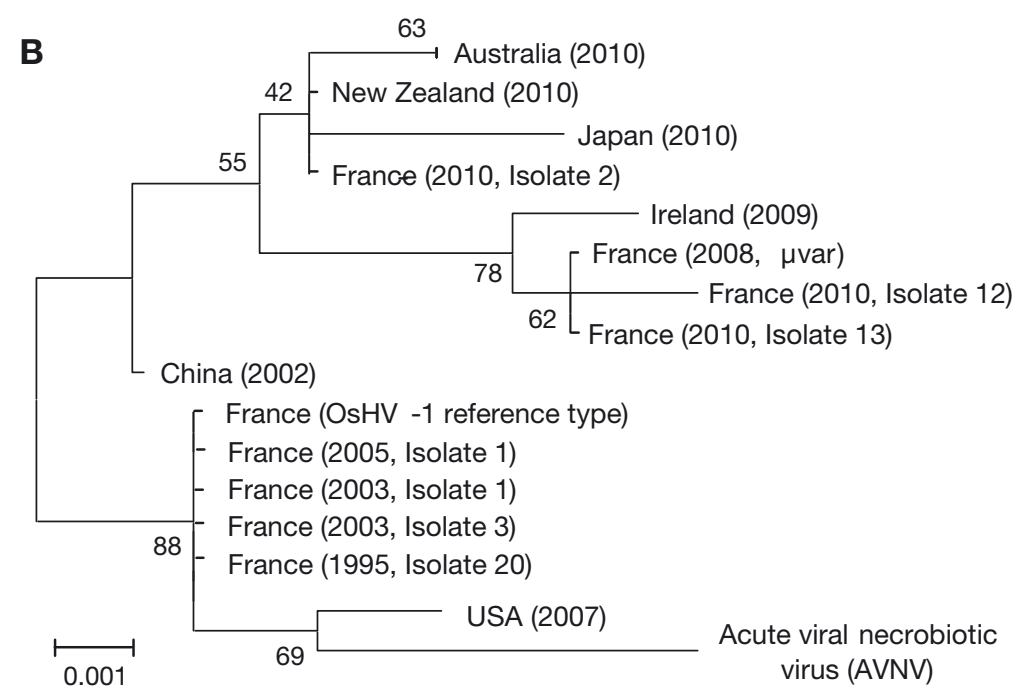

Fig. 4. (A) Alignment of the microsatellite region (within the $\mathrm{C} 2 / \mathrm{C} 6$ sequence) of the Australian OsHV-1 sequence with the same sequence region from other strains of OsHV-1. The Australian strain contains a large deletion in the microsatellite region that is identical to the one seen in the $\mu$-var strain and other OsHV-1 strains responsible for outbreaks in 2010. (B) Phylogenetic tree constructed using the Tamura-Nei maximum-likelihood method and the C2/C6 sequences of various representatives of OsHV-1, including the Australian strain. A total of 622 nucleotide positions were used in the analysis. The Australian OsHV-1 sequence was identical in 3 individual specimens examined; therefore the branches were collapsed into a single node. The Australian strain clusters within the $\mu$-var group rather than the clade containing the OsHV-1 reference type 

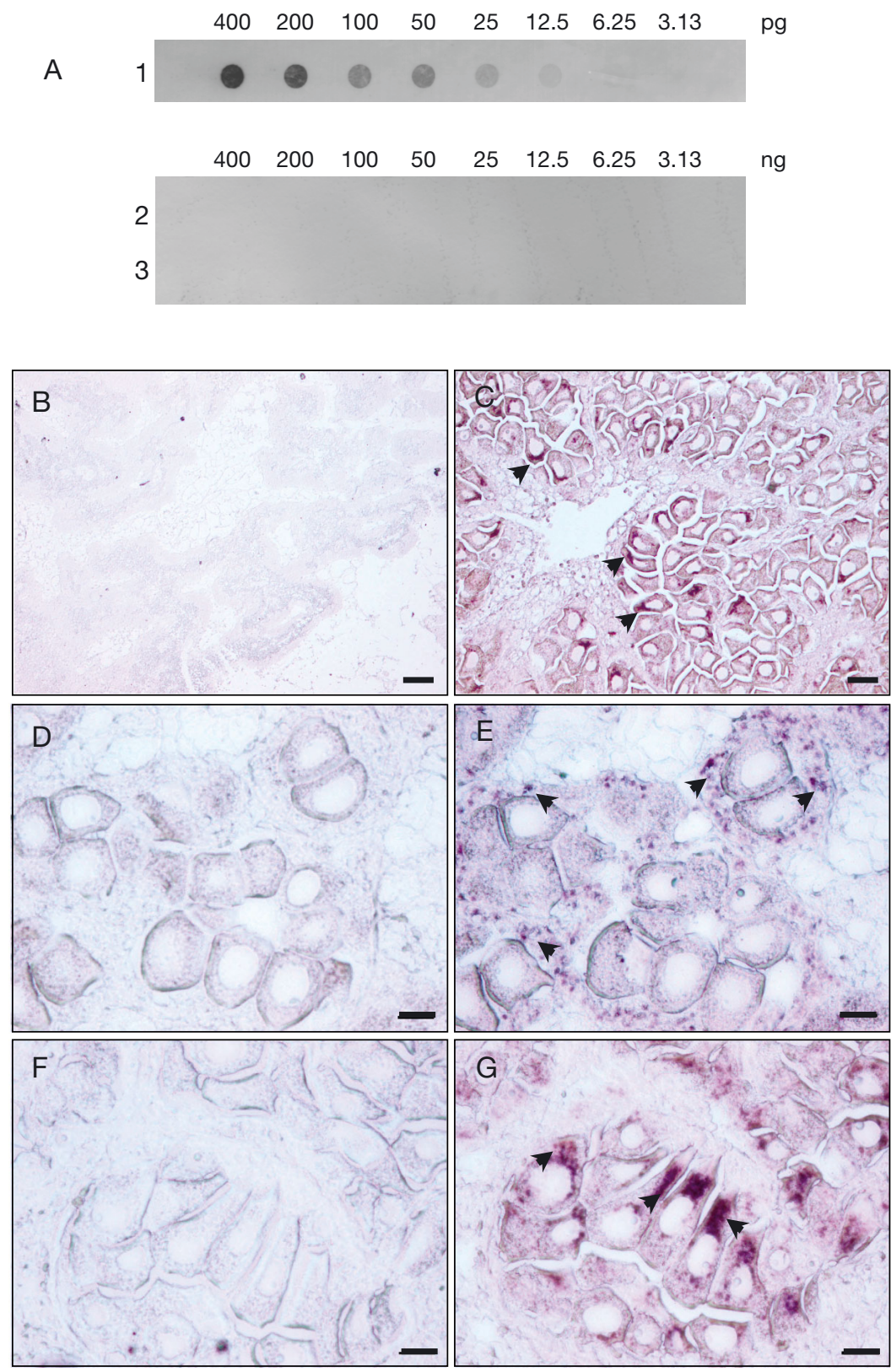

Fig. 5. Crassostrea gigas, Saccostrea glomerata. (A) Specificity and sensitivity of the B3/B2 OsHV-1 DIG-labelled probe tested in a dot blot against OsHV-1 PCR product (Row 1) and total DNA extracted from uninfected C. gigas and $S$. glomerata (Rows 2 and 3). The probe detected $\sim 6 \mathrm{pg}$ of viral DNA, but did not cross-react with either C. gigas or S. glomerata DNA. (B-G) ISH using the OsHV-1 DIG-labelled probe did not detect any virus within $S$. glomerata tissues (B), but $C$. gigas samples that were PCR positive for OsHV-1 stained strongly ( $C$, arrowheads). No staining was observed in infected $C$. gigas oysters that received no probe $(\mathrm{D}, \mathrm{F})$, while strong staining was observed in serial sections from the same oysters that were reacted with the OsHV-1 probe $(\mathrm{E}, \mathrm{G})$. Staining (arrowheads) was largely observed within the gonadal tissue either within haemocytes (E) or within ova (G). Scale bars $=(B-C) 50 \mu \mathrm{m}$, (D-G) $20 \mu \mathrm{m}$ identical to that of Quibray Bay (30.9 ppt, data not shown).

Water temperature data collected from the neighbouring Quibray Bay at the shellfish biotoxin sampling sites (Fig. 1) indicated that the water temperature was 22 to $23^{\circ} \mathrm{C}$ at the time of the outbreaks (Fig. 6C). The increase in water temperature from $18^{\circ} \mathrm{C}$ in early November to $22^{\circ} \mathrm{C}$ in mid-November also coincided with an increase in the detection of Vibrio harveyi in oyster samples collected from the Georges River (Fig. 6C, Table 3).

Counts of harmful phytoplankton species present in the area indicated that toxic diatoms and dinoflagellates bloomed during the early November to early December period. These blooms likely occurred due to a combination of nutrient run-off following the heavy rain in early November and warmer water temperatures. Diatoms belonging to various domoic acid (amnesic shellfish toxin)-producing Pseudo-nitzschia spp. and dinoflagellates of the saxitoxin (paralytic shellfish toxin, PST)-producing Alexandrium fundyense/tamarense/ catanella species complex were present in significant numbers at this time (Fig. 6D). Dinoflagellates of the Prorocentrum genus, which produce diarrhetic shellfish toxin (okadaic acid), were also detected during the mid-November to early December period, but were not present in high numbers (data not shown). Shellfish sampled on 3 separate occasions during the early November to early December period (but not at other times during 2010) returned positive results for the presence PST (Fig. 6D). Despite the presence of a Pseudo-nitzschia bloom and the detection of Prorocentrum spp. neither domoic acid nor okadaic acid were detected within shellfish during this period.

In early January 2011, at the time of placement of the first sentinels and the outbreak in Quibray Bay, rainfall 
Table 3. Crassostrea gigas, Saccostrea glomerata. Percentage of Georges River oysters testing positive for Vibrio harveyi. NS: not sampled

\begin{tabular}{|lcc|}
\hline Date sampled & $\begin{array}{c}\text { C. gigas } \\
\text { (\% positive) }\end{array}$ & $\begin{array}{c}\text { S. glomerata } \\
(\% \text { positive })\end{array}$ \\
\hline 12 Oct 2010 & $\mathrm{NS}$ & 0 \\
9 Nov 2010 & $\mathrm{NS}$ & 0 \\
24 Nov 2010 & 83 & 100 \\
6 Dec 10 & 100 & NS \\
\hline
\end{tabular}

was recorded, but water quality was not greatly affected and the levels of toxic diatoms and dinoflagellates were low during this period. Biotoxin analyses were not performed at this time, but no biotoxin was detected in the preceding 3 shellfish samplings (Fig. 6D).

\section{DISCUSSION}

Studies conducted during the 1990s demonstated the presence of herpesvirus-like particles in Ostrea angasi (flat oyster) (Hine \& Thorne 1997) in Australia and in Crassostrea gigas (Hine et al. 1992) and Ostrea chiliensis (Hine et al. 1998) in New Zealand; however, molecular methods for the detection of OsHV-1 were not used and the identity of these herpesvirus-like particles was not established. In this study we have reported on the first confirmed outbreak of disease due to OsHV-1 infection in C. gigas in Australia. This strain of OsHV-1 caused mass mortality of $C$. gigas spat, juvenile and adult oysters $(>95 \%)$ in Woolooware Bay, Georges River in November and December of 2010 and then in the neighbouring Quibray Bay in January 2011. Sentinel C. gigas oysters placed in Woolooware Bay about 7 wk after the start of the outbreak became infected and experienced approximately $50 \%$ mortality within $1 \mathrm{wk}$ of exposure, indicating the persistence of the virus in the environment.

The high mortality rate observed in the Georges River oysters corresponds with the high viral load detected by PCR and is consistent with prior reports of OsHV-1 outbreaks in Crassostrea gigas juveniles in France (Renault et al. 1994, Segarra et al. 2010), California (Friedman et al. 2005) and Mexico (Vásquez-Yeomans et al. 2010). The Woolooware Bay mortalities coincided with reports of significant losses of $C$. gigas oyster spat in New Zealand, reported in November and December of 2010 (but perhaps commencing as early as March; Interna-
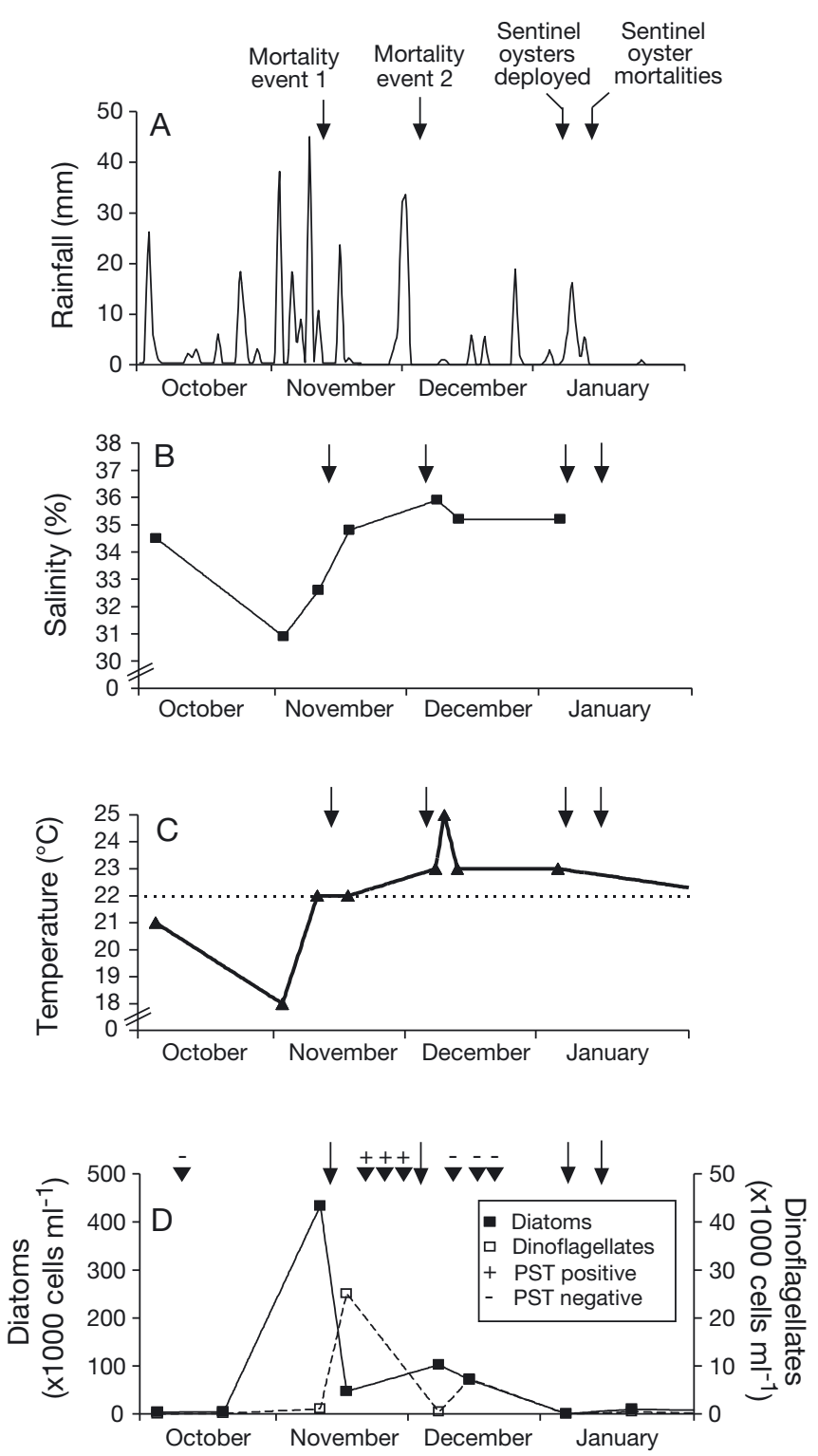

Fig. 6. Summary of environmental data collected during the OsHV-1 outbreaks and the deployment of naïve sentinel oysters in Woolooware Bay. (A) Rainfall recorded in the area from October 2010 to January 2011 indicates that both OsHV-1 outbreaks in Woolooware Bay were preceded by heavy rainfall events. (B) There was sufficient rainfall in early November to have a small impact on the salinity of both Quibray Bay and the intake water at Woolooware Bay (not shown but salinity readings at both sites were identical). (C) Water temperatures during the 2 outbreaks and during the deployment of sentinels were above the optimal temperature for OsHV-1 replication $\left(22^{\circ} \mathrm{C}\right)$. (D) Toxic phytoplankton consisting of Pseudo-nitzschia diatoms and Alexandrium dinoflagellates bloomed during the period immediately preceding the OsHV-1 outbreaks. Oysters collected from the neighbouring Quibray Bay that were tested for the presence of biotoxin (arrowheads) returned positive results for paralytic shellfish toxin (PST) on 3 separate occasions during late November and early December 2010, coinciding with the OsHV-1 related oyster mortalities 
tional OsHV-1 $\mu$-var Workshop 2011) where elevated water temperatures were recorded and subsequent molecular testing also detected the presence of OsHV-1 (Renault et al. 2012).

Phylogenetic analysis indicated that the Australian OsHV-1 is closely related to the strain derived from the New Zealand oysters, as well as 2 other strains causing outbreaks in France and Japan during 2010 (Renault et al. 2012, Shimahara et al. 2012). All of these strains belong to the same cluster as the microvariants of OsHV-1, which have been associated with severe mortalities in Crassostrea gigas since the first description in France in 2008 (Segarra et al. 2010). The origin of the Australian virus remains unknown, though it is strongly suspected that it was unintentionally introduced to Australia. It is perhaps of significance that the site of the first recognised cases in Woolooware Bay is approximately $5 \mathrm{~km}$ upstream from one of Australia's largest shipping container terminals/ports. However, it should be noted that the farmed $C$. gigas population in Quibray Bay did not succumb to disease until about 8 wk after the outbreak was first identified in Woolooware Bay, even though it was nearby and downstream of the affected populations. This may be partially explained by sand shoaling (evident in aerial photographs), which occurs at the entrance to Quibray Bay, thus reducing tidal exchange between the bay and the rest of the estuary.

Close examination of available environmental data collected prior to, during and after the Georges River outbreaks revealed that mortalities at all leases occurred while the water temperature was at or above $22^{\circ} \mathrm{C}$. This temperature is above the minimum shown to be suitable for OsHV-1 replication $\left(16^{\circ} \mathrm{C}\right)$, or required for oyster herpesvirus transmission, in studies performed in other countries (Hine et al. 1998, Arzul et al. 2001b, Schikorski et al. 2011a,b, Pernet et al. 2012). Indeed, OsHV-1 outbreaks have now been observed in the Georges River for 3 seasons, on each occasion once the water temperature rose above $22^{\circ} \mathrm{C}$ (authors' unpubl. observations). This may represent an optimum temperature for rapid transmission and widespread disease occurrence, or may be related to other factors associated with disease expression. Alternatively, disease expression above $22^{\circ} \mathrm{C}$ may reflect local adaptation of Crassostrea gigas to higher water temperatures. The effect of this temperature tolerance range on the oyster immune system may be a key driver of disease susceptibility in C. gigas. Elevated temperatures have also been associated with increased populations of pathogenic Vibrio spp. (Motes et al. 1998,
Zimmerman et al. 2007, Pernet et al. 2012, Zhou et al. 2012), which is consistent with findings from this study demonstrating an increased incidence of $V$. harveyi in oysters collected from Quibray Bay when the water temperature was 22 to $23^{\circ} \mathrm{C}$, compared to oysters collected in early November when the water was at $18^{\circ} \mathrm{C}$.

The initial outbreaks at Leases 1 and 2 in Woolooware Bay were both preceded by heavy rainfall. The effect of rainfall on OsHV-1 transmission has not been investigated; however, rainwater run-off is a known stressor for oysters due to the influx of freshwater and a corresponding decrease in salinity (Levinton et al. 2011). Historical records indicate that both Woolooware and Quibray Bays are high-salinity areas. Due to their proximity to the confluence of Botany Bay and the Tasman Sea, the salinity at these sites rarely drops below 30 ppt. Indeed, the salinity in Woolooware Bay decreased slightly during the rainfall event in early November, just prior to the first outbreak, but nonetheless remained above 30 ppt. Furthermore, salinity did not appear to fluctuate significantly prior to subsequent mortalities; therefore, it is unclear whether salinity has a direct effect on oyster susceptibility to OsHV-1 or whether other parameters associated with rainfall, such as silting or increased nutrient loads, are more likely related to OsHV-1 outbreaks.

Both higher water temperatures and heavy rainfall are known triggers for the bloom of toxic diatoms and dinoflagellates (Hallegraeff 1992), with rainfall causing the discharge of organic and inorganic nitrogenous and phosphorus-containing compounds into the water column (Anderson et al. 2012). Indeed, during late November and early December of 2010, direct cell counts indicated that blooms of toxic phytoplankton were occurring in Quibray Bay, and biotoxin analyses confirmed that PST was present in oysters collected from this location. Observations of a plume of discoloured water and an algal bloom suggest that increased phytoplankton levels arising from nutrient run-off were also present in the neighbouring Woolooware Bay at the time of the OsHV-1 outbreak. Significant rainfall also occurred between sentinel oyster placement in Woolooware and Quibray Bays and subsequent mortalities associated with OsHV-1 (Fig. 6A). The water temperature at this time was above $22^{\circ} \mathrm{C}$; however, toxic phytoplankton were not detected during this period. Interestingly, in addition to the potential to produce biotoxins, phytoplankton are also known to harbour AVNV, a variant of OsHV1 , and it has been proposed that they could act as physical carriers of the virus through the environ- 
ment (Wang et al. 2011). It is possible, therefore, that phytoplankton blooms in the Georges River exacerbated virus spread.

While field observations and experimental transmission studies have demonstrated that the presence of herpesvirus and a water temperature $>16^{\circ} \mathrm{C}$ are sufficient for viral transmission and disease induction (Hine et al. 1998, Pernet et al. 2012), other stress factors are believed to play a role during severe mortality events in Crassostrea gigas, often referred to as 'summer mortality' (Gagnaire et al. 2006, Sauvage et al. 2009). These stressors include toxins, biotoxins from certain species of phytoplankton (Sauvage et al. 2009, Botner et al. 2010), pathogenic Vibrio spp. (Lacoste et al. 2001, Le Roux et al. 2002, Li et al. 2009, Renault et al. 2009, Botner et al. 2010, Pernet et al. 2012) and host metabolic factors related to spawning (Gagnaire et al. 2006, Li et al. 2009). Given that both a bloom of toxic phytoplankton and $V$. harveyi were demonstrated as being present during the OsHV-1 outbreak in Woolooware Bay, it is possible that they contributed to disease severity by compromising the host. The detection of $V$. harveyi in OsHV-1-infected oysters may also reflect opportunistic infection by this pathogen. These factors may also explain the pathology observed in the Saccostrea glomerata specimens. Indeed, the histological changes associated with the presence of PST-producing Alexandrium spp., which include haemocyte accumulation in the connective tissue surrounding the gut and digestive tubules (Haberkorn et al. 2010b), were also observed in the Woolooware Bay oysters.

ISH revealed that in triploid oysters from Woolooware Bay most of the viral DNA was located either within circulating haemocytes (particularly within the gonadal tissue) or within the gametes themselves. The presence of OsHV-1 DNA and proteins within the gonadal tissue of asymptomatic oysters has been reported previously (Arzul et al. 2002). When combined with the detection of viral DNA in 2 d old larvae (Barbosa-Solomieu et al. 2005), these data suggest that vertical transmission of this virus may occur. While triploid Crassostrea gigas are considered functionally sterile, diploid C. gigas were also infected by OsHV-1 in this study. Unfortunately, the tissues collected from diploid C. gigas in this study were of poor quality and not suitable for histological analysis; however, it would be of interest to determine whether OsHV-1 localises within the gametes in diploids as it does in triploids, as spawning could represent an important virus dispersal mechanism. Indeed, OsHV-1 disease dynamics in diploid versus triploid oysters warrants further inves- tigation given that gonadal maturation in diploids is known to result in reduced immune parameters relative to triploids (Gagnaire et al. 2006). Conversely, higher metabolic and haemocyte (phagocytic) activity in triploids could theoretically assist viral trafficking within host tissues. Triploidy in C. gigas has also been shown to result in increased PST accumulation (Haberkorn et al. 2010a), which may be relevant in cases where toxic phytoplankton blooms coincide with OsHV-1 mortalities.

The mechanisms for persistence of OsHV-1 in a population are not well known. However, even though $>99 \%$ of the farmed Crassostrea gigas population had died, it is notable that, of the small proportion of surviving oysters, viral DNA was detected in almost all that were tested 12 and 26 wk after the onset of the outbreak. It is not known whether this DNA represents infectious virus, but it might indicate a source of infection for other oysters.

While molluscan herpesviruses are known to have a broad host range, affecting a number of oyster species (Arzul et al. 2001c, da Silva et al. 2008), as well as clams (Arzul et al. 2001c) and scallops (Arzul et al. 2001b), we noted that Saccostrea glomerata cultivated adjacent to Crassostrea gigas in Woolooware Bay, as well as wild populations of this species in the Parramatta River, did not experience mortalities during OsHV-1 outbreaks and subsequently grew normally. While OsHV-1 DNA was initially detected in samples collected from $S$. glomerata by gel-based PCR, qPCR analysis indicated that the viral load was significantly lower than that in the C. gigas samples $(\mathrm{p}<0.0001)$. Furthermore, ISH failed to detect any viral DNA within S. glomerata tissues, suggesting that $S$. glomerata is not susceptible to infection by OsHV-1. The PCR amplicons derived from S. glomerata samples collected during the outbreak at Lease 1 were likely to have originated from viral DNA in the water that surrounded (or had been filtered through) the oyster. Examination of further S. glomerata specimens by qPCR in situations where there are high viral loads in $C$. gigas have failed to detect any OsHV-1 DNA (authors' unpubl. data).

Despite the fact that Saccostrea glomerata appears to be unaffected by OsHV-1, histological lesions and haemocyte infiltrates were observed in both Crassostrea gigas and S. glomerata from the Georges River. It is known that $S$. glomerata farmed in the Georges River are affected by both QX disease and the winter mortality syndrome (Roughley 1926, Wolf 1972). However, neither QX sporonts nor microcell parasites were observed. Lesions in C. gigas were generally more severe than those observed in $S$. 
glomerata, and, indeed, focal ulcerations were only observed in the C. gigas samples and may therefore be attributable specifically to OsHV-1. Histologic changes consistent in both oyster species were nonspecific and indicate underlying inanition and poor health, suggesting that factors other than infection with OsHV-1 contributed to this pathology.

At the time of the disease outbreaks, freedom of the rest of the Australian Crassostrea gigas and the Saccostrea glomerata populations was supported by a structured virological survey to be described elsewhere (B. Moloney et al. unpubl. data). There was continuing freedom from OsHV-1 disease outside of the Georges and Parramatta River systems for a further 2 yr. However, just prior to submission of this manuscript, on 21 January 2013, a large-scale mortality event due to OsHV-1 was detected in farmed C. gigas in the Hawkesbury River. This estuary is approximately $35 \mathrm{~km}$ north of the Parramatta River and is the nearest population of farmed oysters to the original outbreaks.

Acknowledgements. We thank Dave Barker and Bob Drake for their assistance in providing samples and allowing access to their oyster leases. Anthony Zammit from the Food Authority is gratefully acknowledged for making the phytoplankton, biotoxin and water temperature data available. We are also grateful to Tony Roach and Moreno Julli for conducting the toxicological analyses, and to Damian Collins for assistance in interpreting the statistical analysis. The expertise of technical staff at EMAI in preparing specimens for histopathology and in undertaking the qPCR assays, and of NSW DPI field staff in assisting with sample collection is also gratefully acknowledged.

\section{LITERATURE CITED}

Anderson DM, Cembella AD, Hallegraeff GM (2012) Progress in understanding harmful algal blooms: paradigm shifts and new technologies for research, monitoring, and management. Ann Rev Mar Sci 4:143-176

Arzul I, Nicolas JL, Davison AJ, Renault T (2001a) French scallops: a new host for ostreid herpesvirus-1. Virology 290:342-349

> Arzul I, Renault T, Lipart C (2001b) Experimental herpeslike viral infections in marine bivalves: demonstration of interspecies transmission. Dis Aquat Org 46:1-6

Arzul I, Renault T, Lipart C, Davison AJ (2001c) Evidence for interspecies transmission of oyster herpesvirus in marine bivalves. J Gen Virol 82:865-870

> Arzul I, Renault T, Thebault A, Gerard A (2002) Detection of oyster herpesvirus DNA and proteins in asymptomatic Crassostrea gigas adults. Virus Res 84:151-160

> Barbosa-Solomieu V, Degremont L, Vazquez-Juarez R, Ascencio-Valle F, Boudry P, Renault T (2005) Ostreid herpesvirus 1 (OsHV-1) detection among three successive generations of Pacific oysters (Crassostrea gigas). Virus Res 107:47-56
BOM (Australian Bureau of Meteorology) (2010) Weather and climate. Available at www.bom.gov.au/climate/ data/ (accessed 5 March 2013)

Botner A, Broom D, Doherr MG, Domingo M and others (2010) EFSA panel on animal health and welfare: scientific opinion on the increased mortality events in Pacific oysters, Crassostrea gigas. EFSA Journal 8:1894

> Burge CA, Griffin FJ, Friedman CS (2006) Mortality and herpesvirus infections of the Pacific oyster Crassostrea gigas in Tomales Bay, California, USA. Dis Aquat Org 72: 31-43

Burge CA, Strenge RE, Friedman CS (2011) Detection of the oyster herpesvirus in commercial bivalve in northern California, USA: conventional and quantitative PCR. Dis Aquat Org 94:107-116

Cotter E, Malham SK, O'Keeffe S, Lynch SA and others (2010) Summer mortality of the Pacific oyster, Crassostrea gigas, in the Irish Sea: the influence of growth, biochemistry and gametogenesis. Aquaculture 303:8-21

$>$ da Silva PM, Renault T, Fuentes J, Villalba A (2008) Herpesvirus infection in European flat oysters Ostrea edulis obtained from brood stocks of various geographic origins and grown in Galicia (NW Spain). Dis Aquat Org 78: 181-188

> Davison AJ, Eberle R, Ehlers B, Hayward GS and others (2009) The order Herpesvirales. Arch Virol 154:171-177

$>$ Dundon WG, Arzul I, Omnes E, Robert M and others (2011) Detection of type 1 ostreid herpes variant (OsHV-1 microvar) with no associated mortality in French-origin Pacific cupped oyster Crassostrea gigas farmed in Italy. Aquaculture 314:49-52

FAO (Food and Agriculture Organization of the United Nations) (2013) Species fact sheet: Crassostrea gigas (Thunberg, 1793). FAO, Rome. Available at www.fao. org/fishery/species/3514/en (accessed 17 May 2013)

> Farley CA, Banfield WG, Kasnic G Jr, Foster WS (1972) Oyster herpes-type virus. Science 178:759-760

> Friedman CS, Estes RM, Stokes NA, Burge CA and others (2005) Herpes virus in juvenile Pacific oysters Crassostrea gigas from Tomales Bay, California, coincides with summer mortality episodes. Dis Aquat Org 63:33-41

> Gagnaire B, Soletchnik P, Madec P, Geairon P, Le Moine O, Renault T (2006) Diploid and triploid Pacific oysters Crassostrea gigas (Thunberg), reared at two heights above sediment in Marennes-Oleron Basin, France: difference in mortality, sexual maturation and hemocyte parameters. Aquaculture 254:606-616

> Haberkorn H, Lambert C, Le Goic N, Gueguen M and others (2010a) Effects of Alexandrium minutum exposure upon physiological and hematological variables of diploid and triploid oysters, Crassostrea gigas. Aquat Toxicol 97: 96-108

> Haberkorn H, Lambert C, Le Goic N, Moal J and others (2010b) Effects of Alexandrium minutum exposure on nutrition-related processes and reproductive output in oysters Crassostrea gigas. Harmful Algae 9:427-439

Hallegraeff GM (1992) Harmful algal blooms in the Australian region. Mar Pollut Bull 25:186-190

Hine PM, Thorne T (1997) Replication of herpes-like viruses in haemocytes of adult flat oysters Ostrea angasi: an ultrastructural study. Dis Aquat Org 29:189-196

Hine PM, Wesney B, Hay BE (1992) Herpesviruses associated with mortalities among hatchery-reared larval Pacific oysters Crassostrea gigas. Dis Aquat Org 12: 135-142 
Hine PM, Wesney B, Besant P (1998) Replication of a herpeslike virus in larvae of the flat oyster Tiostrea chilensis at ambient temperatures. Dis Aquat Org 32:161-171

International OsHV-1 $\mu$-var workshop (2011) Final report OsHV-1 $\mu$-var. Available at www.oysterstasmania.org/ downloads/Oyster-Herpes-Virus-Workshop-Final-Report111107.pdf (accessed 5 March 2013)

- Lacoste A, Jalabert F, Malham S, Cueff A and others (2001) A Vibrio splendidus strain is associated with summer mortality of juvenile oysters Crassostrea gigas in the Bay of Morlaix (North Brittany, France). Dis Aquat Org 46: 139-145

Larkin MA, Blackshields G, Brown NP, Chenna R and others (2007) Clustal W and Clustal X version 2.0. Bioinformatics 23:2947-2948

> Le Deuff RM, Renault T, Gerard A (1996) Effects of temperature on herpes-like virus detection among hatcheryreared larval Pacific oyster Crassostrea gigas. Dis Aquat Org 24:149-157

> Le Roux F, Gay M, Lambert C, Waechter M and others (2002) Comparative analysis of Vibrio splendidusrelated strains isolated during Crassostrea gigas mortality events. Aquat Living Resour 15:251-258

Levinton J, Doall M, Ralston D, Starke A, Allam B (2011) Climate change, precipitation and impacts on an estuarine refuge from disease. PLoS ONE 6:e18849

Li Y, Qin JG, Li X, Benkendorff K (2009) Spawningdependent stress responses in Pacific oysters Crassostrea gigas: a simulated bacterial challenge in oysters. Aquaculture 293:164-171

> Lynch SA, Carlsson J, O'Reilly AO, Culloty SC (2012) A previously undescribed ostreid herpes virus (OsHV-1) genotype detected in the Pacific oyster, Crassostrea gigas, in Ireland. Parasitology 139:1526-1532

Malham SK, Cotter E, O'Keeffe S, Lynch S and others (2009) Summer mortality of the Pacific oyster, Crassostrea gigas, in the Irish Sea: the influence of temperature and nutrients on health and survival. Aquaculture 287:128-138

Martenot C, Oden E, Travaille E, Malas JP, Houssin M (2010) Comparison of two real-time PCR methods for detection of ostreid herpesvirus 1 in the Pacific oyster Crassostrea gigas. J Virol Methods 170:86-89

Miller PA, Elliot NG, Koutoulis A, Kube PD, Vaillancourt RE (2012) Genetic diversity of cultured, naturalized and native Pacific oysters, Crassostrea gigas, determined from multiplexed microsatellite markers. J Shellfish Res 31:611-617

> Motes ML, DePaola A, Cook DW, Veazey JE and others (1998) Influence of water temperature and salinity on Vibrio vulnificus in Northern Gulf and Atlantic Coast oysters (Crassostrea virginica). Appl Environ Microbiol 64:1459-1465

Nicholas KB, Nicholas HBJ, Deerfield DWI (1997) GeneDoc: analysis and visualization of genetic variation. EMBNET.NEWS 4:14

NSW DPI (Department of Primary Industries) (2011) Protocol for investigating and reporting fish kills. Available at www.dpi.nsw.gov.au/_data/assets/pdf_file/0007/378385/ fish-kill-protocol.pdf (accessed 5 March 2013)

> Pang L, Zhang XH, Zhong Y, Chen J, Li Y, Austin B (2006) Identification of Vibrio harveyi using PCR amplification of the toxR gene. Lett Appl Microbiol 43:249-255

> Pernet F, Barret J, Le Gall P, Corporeau C and others (2012) Mass mortalities of Pacific oysters Crassostrea gigas reflect infectious diseases and vary with farming practices in the Mediterranean Thau lagoon, France. Aquacult Environ Interact 2:215-237

Renault T, Cochennec N, Le Deuff RM, Chollet R (1994) Herpes-like virus infecting Japanese oyster (Crassostrea gigas) spat. Bull Eur Assoc Fish Pathol 14:64-66

Renault T, Allain G, Arzul I, Chollet B and others (2009) Summer mortality outbreaks of French Pacific oysters Crassostrea gigas in 2008 and 2009. In: Proc 14th European Association of Fish Pathologists Int Conf, 14-17 Sep 2009, Prague. Available at http://archimer.ifremer.fr/ doc/00014/12554/9420.pdf

$>$ Renault T, Moreau P, Faury N, Pepin JF, Segarra A, Webb S (2012) Analysis of clinical ostreid herpesvirus 1 (Malacoherpesviridae) specimens by sequencing amplified fragments from three virus genome areas. J Virol 86: 5942-5947

Roughley TC (1926) An investigation of the cause of an oyster mortality on the Georges River, New South Wales, 1924-5. Proc Linn Soc NSW 51:446-491

Sauvage C, Pepin JF, Lapegue S, Boudry P, Renault T (2009) Ostreid herpes virus 1 infection in families of the Pacific oyster, Crassostrea gigas, during a summer mortality outbreak: differences in viral DNA detection and quantification using real-time PCR. Virus Res 142:181-187

Savin KW, Cocks BG, Wong F, Sawbridge T, Cogan N, Savage D, Warner S (2010) A neurotropic herpesvirus infecting the gastropod, abalone, shares ancestry with oyster herpesvirus and a herpesvirus associated with the amphioxus genome. Virol J 7:308

Schikorski D, Faury N, Pepin JF, Saulnier D, Tourbiez D, Renault T (2011a) Experimental ostreid herpesvirus 1 infection of the Pacific oyster Crassostrea gigas: kinetics of virus DNA detection by q-PCR in seawater and in oyster samples. Virus Res 155:28-34

Schikorski D, Renault T, Saulnier D, Faury N, Moreau P, Pepin JF (2011b) Experimental infection of Pacific oyster Crassostrea gigas spat by ostreid herpesvirus 1: demonstration of oyster spat susceptibility. Vet Res 42:27

Schmider E, Ziegler M, Danay E, Beyer L, Buhner M (2010) Is it really robust? Reinvestigating the robustness of ANOVA against violations of the normal distribution assumption. Methodol Eur J Res Methods Behav Soc Sci 6:147-151

Segarra A, Pepin JF, Arzul I, Morga B, Faury N, Renault T (2010) Detection and description of a particular ostreid herpesvirus 1 genotype associated with massive mortality outbreaks of Pacific oysters, Crassostrea gigas, in France in 2008. Virus Res 153:92-99

Shimahara Y, Kurita J, Kiryu I, Nishioka T and others (2012) Surveillance of type 1 ostreid herpesvirus (OsHV-1) variants in Japan. Fish Pathol 47:129-136

Smith IR, Nell JA, Adlard RD (2000) The effect of growing height and growing method on winter mortality in diploid and triploid Sydney rock oysters, Saccostrea glomerata (Gould, 1850). Aquaculture 185:197-205

Tamura K, Peterson D, Peterson N, Stecher G, Nei M, Kumar S (2011) MEGA5: molecular evolutionary genetics analysis using maximum likelihood, evolutionary distance, and maximum parsimony methods. Mol Biol Evol 28: 2731-2739

> Tan J, Lancaster M, Hyatt A, van Driel R, Wong F, Warner S (2008) Purification of a herpes-like virus from abalone (Haliotis spp.) with ganglioneuritis and detection by transmission electron microscopy. J Virol Methods 149: 338-341 
Tang B, Liu B, Wang X, Yue X, Xiang J (2010) Physiological and immune responses of Zhikong scallop Chlamys farreri to the acute viral necrobiotic virus infection. Fish Shellfish Immunol 29:42-48

Vásquez-Yeomans R, Garcia-Ortega M, Caceres-Martinez J (2010) Gill erosion and herpesvirus in Crassostrea gigas cultured in Baja California, Mexico. Dis Aquat Org 89: 137-144

Wang N, Ren Wc, Cai Yy, Wang Cm (2011) Detection of acute viral necrosis virus (AVNV) in plankton using FQPCR during a molecular epidemiology survey. J Fish China 34:1566-1571

Editorial responsibility: Mike Hine,

Fouras, France
Wolf PH (1972) Occurrence of a haplosporidian in Sydney rock oysters (Crassostrea commercialis) from Moreton Bay Queensland, Australia. J Invertebr Pathol 19:416-417

$>$ Zhou J, Fang W, Yang X, Zhou S and others (2012) A nonluminescent and highly virulent Vibrio harveyi strain is associated with 'bacterial white tail disease' of Litopenaeus vannamei shrimp. PLoS ONE 7:e29961

- Zimmerman AM, DePaola A, Bowers JC, Krantz JA, Nordstrom JL, Johnson CN, Grimes DJ (2007) Variability of total and pathogenic Vibrio parahaemolyticus densities in northern Gulf of Mexico water and oysters. Appl Environ Microbiol 73:7589-7596

Submitted: March 14, 2013; Accepted: May 23, 2013

Proofs received from author(s): July 3, 2013 